\title{
両側臼歯欠損が顎関節滑液のグリコサミノグリカンに及ぼす 影響についての生化学的研究
}

\author{
荒木春美

\begin{abstract}
Effect of bilateral extraction of molars on glycosaminoglycans
\end{abstract} \\ in the synovial fluid of the temporomandibular joint in monkeys
}

\author{
Harumi ARAKI
}

\begin{abstract}
This study was designed to determine the effect of bilateral extraction of all molars and premolars on glycosaminoglycans (GAG) in the synovial fluid of the monkey temporomandibular joint (TMJ). TMJ radiographs were taken using standard techniques at intervals of $2,4,8,16$, and 24 weeks following surgery. The synovial fluid was digested with pronase $\mathrm{E}$ and GAG were extracted using CPC at intervals of 2, 8, 16, and 24 weeks following surgery. Qualitative and quantitative changes in the GAG were examined by the carbazole reaction and electrophoresis on a cellulose acetate strip. The molecular weight distribution of GAG was examined by gel chromatography.
\end{abstract}

The following results were obtained

1) No morphological changes were observed in the condylar head or articular eminence, although the position of the condyle changed in a superoposterior direction in the 16 and 24 week groups.

2) The GAG was composed of hyaluronic acid (HA) only.

3) HA concentration as uronic acid was initially $2.13 \mathrm{mg} / \mathrm{ml}$, gradually decreasing with time.

4) Gel chromatogrophy-measured HA in the experimental groups was eluated later than the control group, indicating a decrease in the molecular size of $\mathrm{HA}$ in the experimental groups. Decreased molecular size of $\mathrm{HA}$ was observed up until the 16 week; an increase to the 2 week level was observed in the 24 week group.

It is suggested that bilateral extraction of molars in monkeys caused quantitative and qualitative changes in the $\mathrm{HA}$ of the synovial fluid.

Key words : synovial fluid (滑液), temporomandibular joint (顎関節), occlusal alteration (咬合異常)

緒言

近年，頱関節部疼痛や雑音を主症状とする須関節症の

大阪药科大学口腔外科学教室第 1 講座

（主任：白数力也教授）

First Department of Oral and Maxillofacial Surgery, Osaka Dental University (Chief: Prof. Rikiya Shirasu)

受付日：昭和63年 12 月 20 日
患者は増加する傾向にあり, それについての臨床的, あ るいは実験的報告が数多く集積されてきている。なかで も, 顎関節に及ぼす咬合異常の影響については, 組織学 的 1 4) 拉よび超微構造的 5 , 6) な検索がいくつか行われてい るが，滑液に及ぼす影響については，わずかに森本》が 片側咬合挙上時の顎関節滑液を対象にヒアルロン酸（以 下， HA と略す）の量的变動について報告した知見があ るにすぎない，そこでわたくしは，顎関節滑液の性状な らびに咬合異常に伴う質的, 量的变動を明らかにするた め，サル顎関節を用いて，正常滑液のグリコサミノグリ 


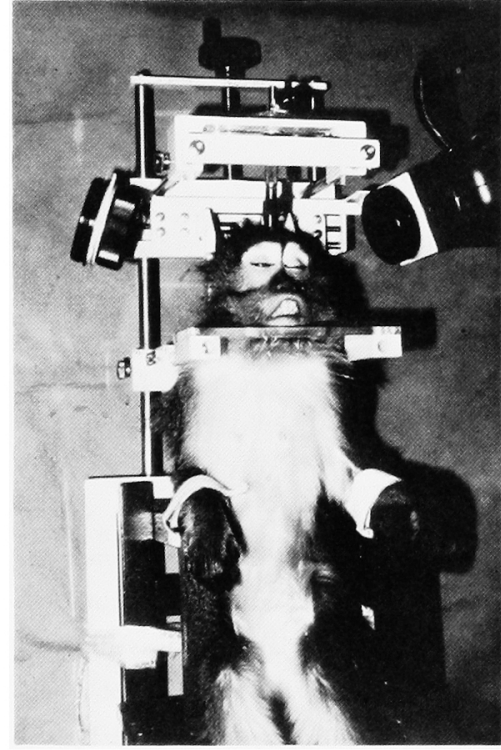

写真 1 サル用靧関節規格エックス線 撮影装置と撮影時の状態

カン（以下，GAG と略す）の組成を検索し，さらに両 側田歯欠損に起因する咬合異常時の顎関節滑液 GAG の 分子種レベルの動態を酵素消化法，電気泳動法の併用で 生化学的に分析し，その分子量分布の変動をゲル濾過法 による溶出パターンから解析した。

\section{実験材料および方法}

\section{1. 実験材料}

実験には歯牙年数 $\mathrm{M}_{2} / \mathrm{M}_{2}$ の雌性 Macaca fascicularis 20 頭（体重 $1.72 \sim 3.20 \mathrm{~kg}$ ）を用いた。实験期間 中，サル用固型飼料（オリエンタル酵母，東京）および 生甘藷を用いて実験動物を同一条件下で飼育した，実験 動物を 1 群 4 頭と乙て 5 群にわけ，両側上頸 $\mathrm{P}_{1} ， \mathrm{P}_{2}$ ， $\mathrm{M}_{1}$ および $\mathrm{M}_{2}$ を抜歯後，両側下䫇 $\mathrm{P}_{1} ， \mathrm{P}_{2}, \mathrm{M}_{1}$ およ び $\mathrm{M}_{2}$ の米冠を虍頸部まで削合し，術後 $2 ， 8 ， 16$ およ び24週経過したものをそれぞれ実験群とした。また未処 置のものを対照群とした。

\section{2. 実験方法}

1) 肉眼的観察

実験群の各群 4 頭は，術前と術後 $2 \sim 24$ 週の経過時 に，肉眼による口膑内所見の観察を行った.

2）顎関節規格エックス楾的分析

(1) 撮影法

下顎頭と下㖽䔰の形態的変化および下顎頭の位置的変 化をェックス線的に推察するために，実験群および対照 群の各 1 頭を, 術前, 術後 $2 \sim 24$ 週の経過時に荒木ら ${ }^{8)}$ の考案したサル用顎関節規格エックス線写真撮影装还を

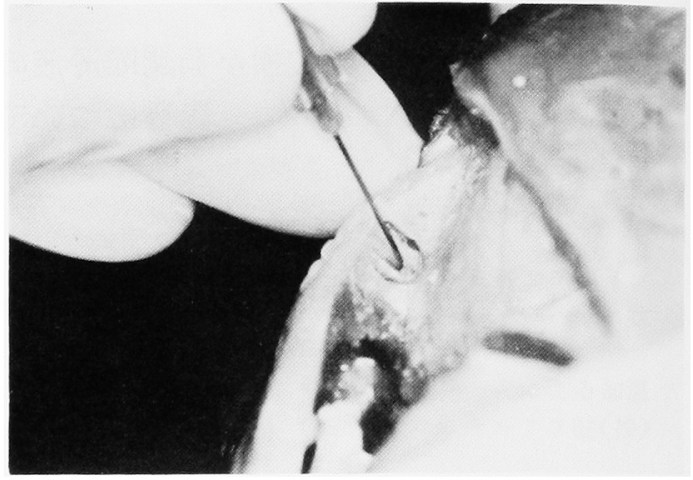

写真 2 上関節空滑液採取法

用いてェックス線写真撮影を行った（写真1）.

(2) エックス線写真分析法

撮影したエックス線写真は，万能投影機 (Nikon Profile Projection Model V-16) を用いて 5 倍に桩大した 像をトレースし，外耳孔，下䫇窩を基準として重ね合わ せを行い術前と術後の各経過時における下買頭と下顎窩 の形態的変化执よび下顎頭の位置的変化を観察した。

3）靧関節滑液の生化学的分析

(1) 試料採取法

実験群掞よび対照群の各群 4 頭は, ペントバルビター ルによる全身麻酔下で断頭し，森本の方法”に準じて上 下顎関節滑液を採取した（写真 2)，採取した試料は測 定時まで $-30^{\circ} \mathrm{C}$ で涷結保存した.

(2) GAG の抽出法

実験群扣よび対照群の上下顎関節滑夜は $0.1 \mathrm{M}$ リン酸 緩衙液（pH 7.8）中,プロナーゼ E（科研製薬，東京） で $37^{\circ} \mathrm{C} ， 24$ 時間消化した．未消化物を遠心(3,000 rpm, 10分間) 除去後, その上清に終濃度が $0.03 \sim 0.04 \mathrm{M}$ と なるよらに塩化ナトリウムを加えた。 さらにセチルピリ ジニウムクロライドを白濁が生じなくなるまで加え， $4^{\circ} \mathrm{C} ， 24$ 時間放置 L，沈渣を遠心 $(3,000 \mathrm{rpm}, 20$ 分間) 後，回収して蒸留水に溶解し，さらに 5 倍量 (v/v) の $1 \%$ 酢酸カリウムーエタノール溶液を加兄て $4{ }^{\circ} \mathrm{C}, 5$ 時 間放置した，遠心 $(3,000 \mathrm{rpm}, 20$ 分間) 後, 回収して得 た沈涾を，1\%酢酸カリウムーエタノール溶液で 3 回洗浄 したのち, 蒸留水に溶解後凍結乾學して GAG 試料とし た (図1).

（3）七ルロース・アセテート膜電気泳動法

対照群の上下䫇関節滑液より抽出精製した GAG の 同定には，セルロース・アセテート膜二次元電気泳動 を，GAG 特異分解酵素による消化後の GAG 分子種の 確認と実験群の上下䫇関節滑液より抽出精製した GAG の同定には，セルロース・アセテート膜一次元電気泳動 を行った. 一次元電気泳動では SM 11200 (Sartorius, Germany）を支持体とし，0.2 M 酢酸カルシウム溶夜 で, $1 \mathrm{~mA} / \mathrm{cm}, 3$ 時間泳動しだ，二次元電気泳動では 
Vol. 35 No. 5 両㑡臼㳡欠損が顎関節滑液のグリコサミノグリカンに及ほす影遙についての生化学的研究 1095

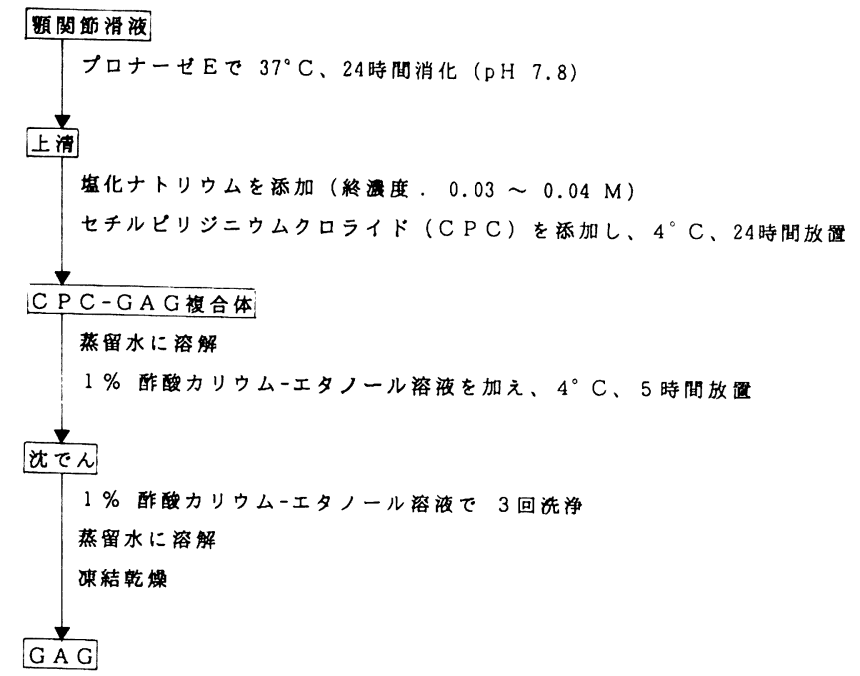

図 1 顎関節滑液 GAG の抽出法

表 1 醋素消化の条件

\begin{tabular}{|c|c|c|c|c|c|}
\hline 酵 素 & 綏衙液 & $\mathrm{pH}$ & $\begin{array}{c}\text { 消化温度 } \\
\left({ }^{\circ} \mathrm{C}\right)\end{array}$ & $\begin{array}{c}\text { 消化時間 } \\
\text { (时間) }\end{array}$ & 酥素溦度 \\
\hline $\begin{array}{l}\text { ヘトレプトミセス } \\
\text { ヒアルロ }\end{array}$ & $\begin{array}{l}0.05 \mathrm{M} \\
\text { 酢酸 }\end{array}$ & 5.0 & 50 & 24 & $\begin{array}{l}100 \\
\text { T.R.U./ml }\end{array}$ \\
\hline $\begin{array}{l}\text { コンドロイチナーゼ } \\
\mathrm{ABC}\end{array}$ & $\begin{array}{c}0.1 \mathrm{M} \\
\text { トリス塩酸 }\end{array}$ & 8.0 & 37 & 24 & $\begin{array}{c}5 \\
\text { units } / \mathrm{ml}\end{array}$ \\
\hline
\end{tabular}

セパラックス（常光産業，東京）を支持体とし，一次展 開は $0.1 \mathrm{M}$ ピリジン $-0.47 \mathrm{M}$ ギ酸緩衝液（pH 3.0） で $1 \mathrm{~mA} / \mathrm{cm}, 1$ 時間, 二次展開は $0.1 \mathrm{M}$ 酢酸バリウ 么溶液（pH 8.0）で $1 \mathrm{~mA} / \mathrm{cm} ， 3$ 時間泳動した。泳 動後のアセテート膜は, $0.1 \%$ ルシアンブルー $8 \mathrm{GS}$ の $3 \%$ 酢酸溶液で 20 分間染色後，1\%酢酸溶液で数回脱色 し, 流水でよく水洗した。標準にはヒアルロン酸(Sigma, USA), コンドロイチン硫酸 AおよびC，デルマタン硫 酸、一パラン硫酸およびヘパリン（以上，生化学工業， 東京）の6 種類の GAG を用いた.

(4) 酵素消化法

対照群の上下顎関節滑液より抽出精製した GAG は, ストレプトミセスヒアルロニダーゼ(10)おびュンドロイ チナーゼ $\mathrm{ABC}^{11)}$ による酵素消化試験を行った。前者は $0.05 \mathrm{M}$ 酢酸緩衝液 ( $\mathrm{pH} 5.0$ ) 中で, $50^{\circ} \mathrm{C} ， 24$ 時間, 後 者は 0.1 M トリス-塩酸緩衝液 $\left(\mathrm{pH} \mathrm{8.0)中で,} 37^{\circ} \mathrm{C}\right.$, 24時間それぞれ反応させた（表 1 ）.

(5) GAG の定量法

串験群および対照群の上䫈関節滑液より抽出精製した

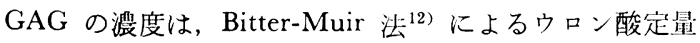

值から求めた。

(6) Sepharose CL 2 B ゲル滤過法

実験群および対照群とも上下顎関節滑液より抽出精製 した GAG は Sepharose CL 2 B ゲル滤過法で分画し た. GAG を 0.5 M 酢酸緩衝液 $(\mathrm{pH}$ 6.8) に溶解し, 同緩衝液で平衡化した Sepharose CL 2 B カラム $(0.9 \times$ $60 \mathrm{~cm}$ ) に注入した。溶出は同緩衝液（流速 $3.2 \mathrm{ml} /$ 時 間）で行い， $0.8 \mathrm{ml}$ ずつ画分を回収しウロン酸量を測 定した。試料量が微量のためウロン酸量の測定には次に 述べるように䖝光修飾法と高速液体クロマトグラフィー (以下, HPLC と略す) を併用 ${ }^{13)}$ した。 各画分は PD-10 カラムで脱塩後, $0.05 \mathrm{M}$ 塩酸中で $110^{\circ} \mathrm{C}, 16$ 時間加水分 解した。冷却後, 蒸発乾固したものに, 内標準として $0.01 \%$ ガラクッロン酸 $100 \mu l$ を加え, さらに50\%トリ エチルアミンーエタノール溶液 $100 \mu l$ を加えて $40^{\circ} \mathrm{C}$, 45 分間反応後凍結乾燥した。凍結乾燥試料は $10 \mu \mathrm{l}$ の蒸 留水に溶解後, 螢光修飾のために $1 \%$ ダンシルヒドラジ ンーエタノール溶液 $20 \mu \mathrm{l}$ と $0.75 \%$ トリクロル酢酸ーエタ ノール溶液 $20 \mu l$ を加え, $40^{\circ} \mathrm{C}, 60$ 分間反応させた。 その後室温に泠却し, 反応液の一部を分析試料として 


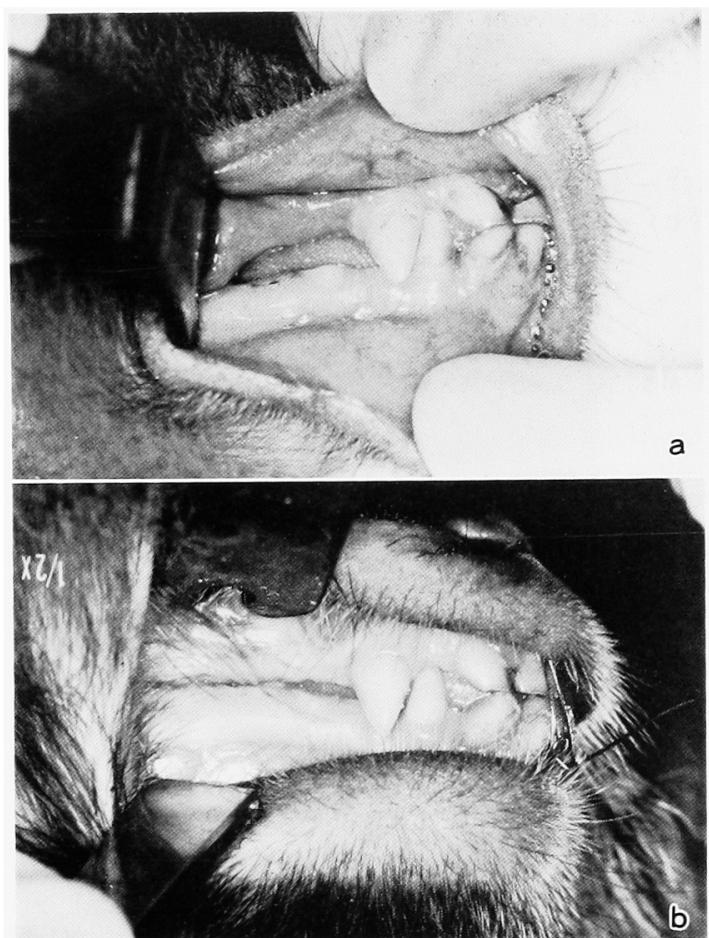

写真 3 口腔内写真
a：術後 2 週
b：術後24週

HPLC に $1 \sim 20 \mu l$ 注入した，装置は日立 650-60 形分 光管光光度計付き高速液体クロマトグラフ（日立638-50 形) で, カラムは TSK-gel $\mathrm{NH}_{2}-60(4.6 \mathrm{~mm}$ i.d. $\times 250$ $\mathrm{mm})$, 溶離液はアセトニトリル $-0.1 \mathrm{M}$ 酢酸緩衝液 $(\mathrm{pH}$ $5.6 ， 5 / 1: \mathrm{v} / \mathrm{v})$ を用い，流速は $1.0 \mathrm{ml} /$ 分とした。

\section{実 験 結 果}

\section{1. 肉眼的観察}

実験群では術後 2 週で抜菡窩は治㾻し，16〜24週で上

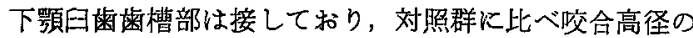
低下を認めた（写真 $3 \mathbf{a , b}$ ).

\section{2. 䪽関節規格エックス線的分析}

撮影した規格エックス線写真上では, 奏験群および対 照群の下䫇頍および下靧窩に経日的な形態的変化は認め られなかった（写真 $4 \mathbf{a}, \mathbf{b}, 5 \mathbf{a}, \mathbf{b}$ ).

実験群の各群と対照群のェックス線像をトレースした ものを重ね合わせて比較したところ，與聴道線を基準と して実験群の下顎頭は左右両側とす術後16 24週で後上 方方向へ偏位した（図 $2 \mathbf{a}, \mathbf{b}$ ).

3. 顎関節滑液の生化学的分析

1) 顎関節滑液中の GAG の組成
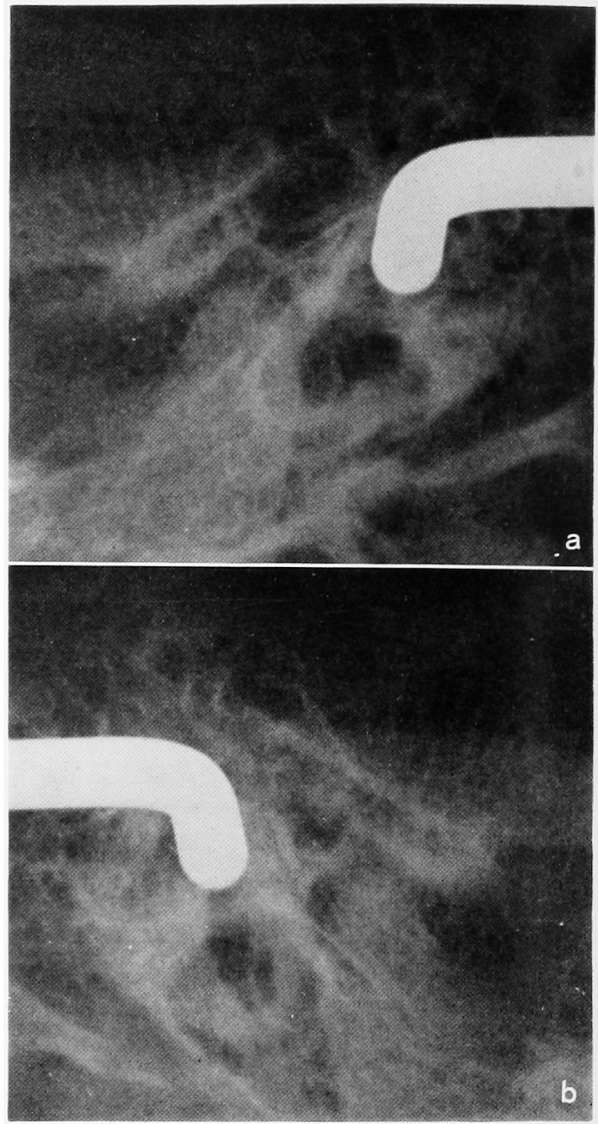

写真 4 止前の箱関節規格エックス線写真 $\mathrm{a}$ : 左側 $\mathrm{b}$ ：右側

対照群顎関節滑液 GAG の二次元電気泳動像では, 標準の HA に相当する 位置に明膫なスポットが喼めら れたのみで，他の標準に相当する位置にスポットは認め られず (图3)，GAG 特異分解酵素による酵素消化後 の一次元電気泳動像でも，HA に相当するスポットは消 失し, 新たなスポットの出現す認められなかった(図 4). また，実験群各群の罰関節滑液 GAG の一次元電気泳動 像では，いずれる HA に相当するスポットのみで他の スポットは認められなかった（図５）.

2）顎関節滑液中の GAG 濃度の変動

䫇関節滑液 GAG 濃度をウロン酸量を指標として示す と, 対照群では $2.13 \mathrm{mg} / \mathrm{ml}$, 実験群では 2 週群で 1.62 $\mathrm{mg} / \mathrm{ml}, 8$ 週群で $1.51 \mathrm{mg} / \mathrm{ml}, 16$ 週群で $1.18 \mathrm{mg} / \mathrm{ml}$, 扰よび 24 週群で $1.12 \mathrm{mg} / \mathrm{m} l$ のウロン酸が含まれてい た（表 2 ).

実験群では術後 2 24週にかけて経日的に GAG 濃度

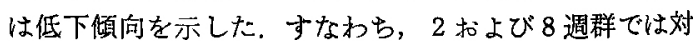
照群に比べ有意 $(\mathbf{p}<0.05, \mathrm{p}<0.05)$ に低值を示し，ま 


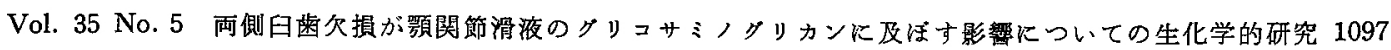
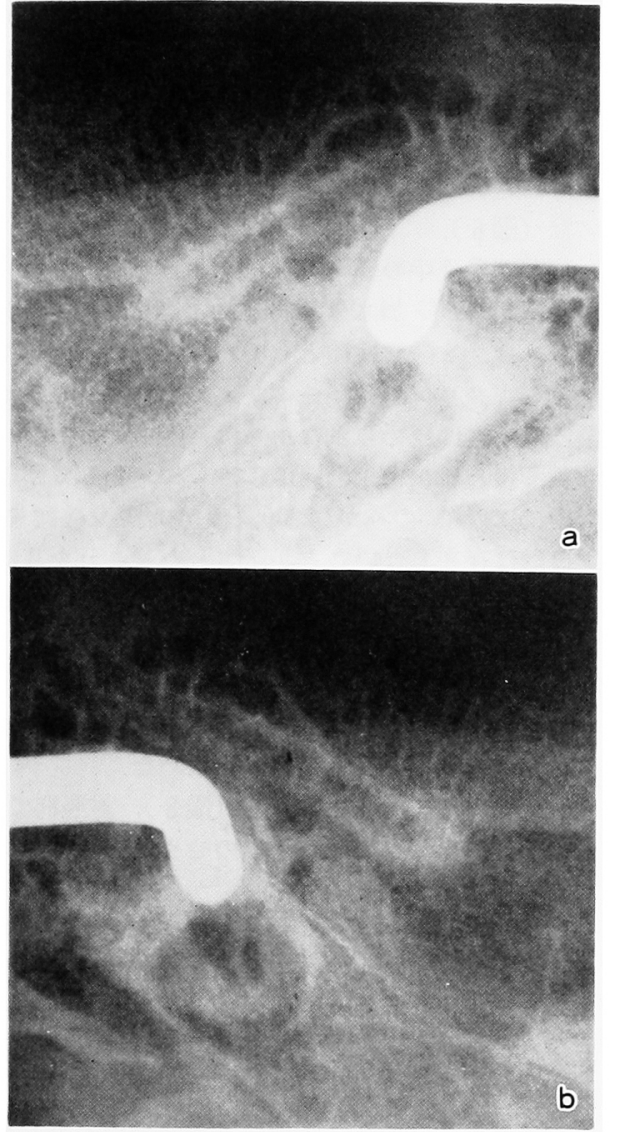

写真 5 術後24週の買関節規格エックス線写真 $\mathrm{a}$ 左側 $\mathrm{b}$ : 右側

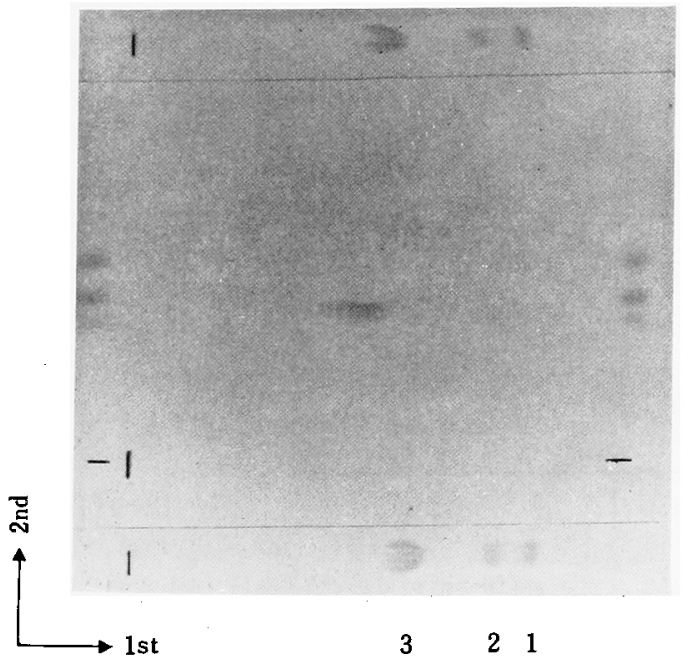

図 3 対照群買関節滑液 GAG の二次元電気泳動区 標準 : 1. コンドロイチン硫酸 A，2. デルマタン硫 酸, 3. ヒフルロン酸, 4. ヘパラン硫酸
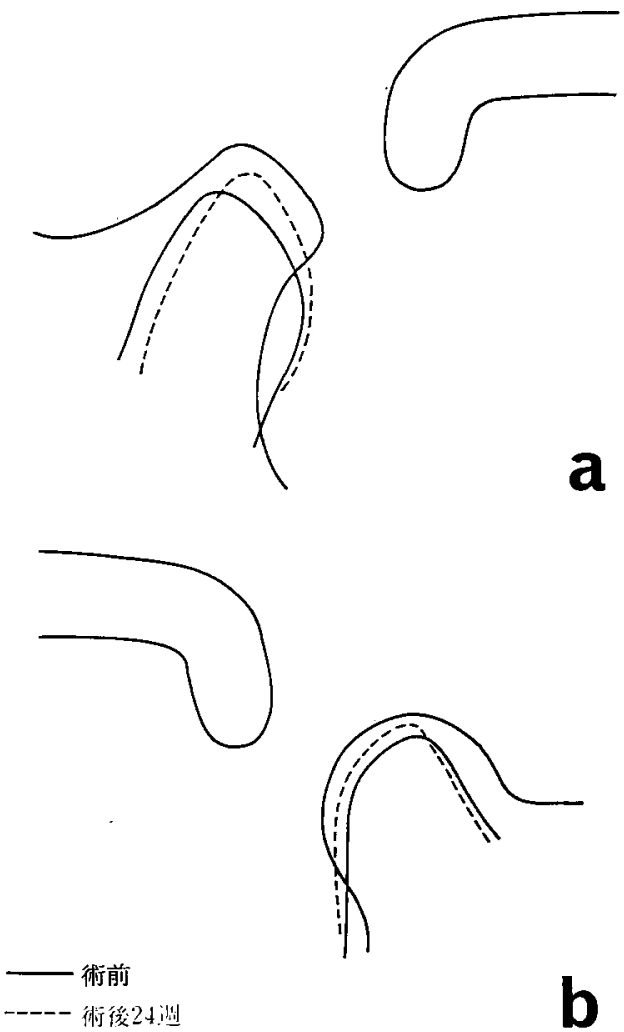

b

図 2 術前と術後24週に撮影したエックス線 像をトレースしたものの重站合わせ
$\mathrm{a}:$ 左側
b : 右側

a

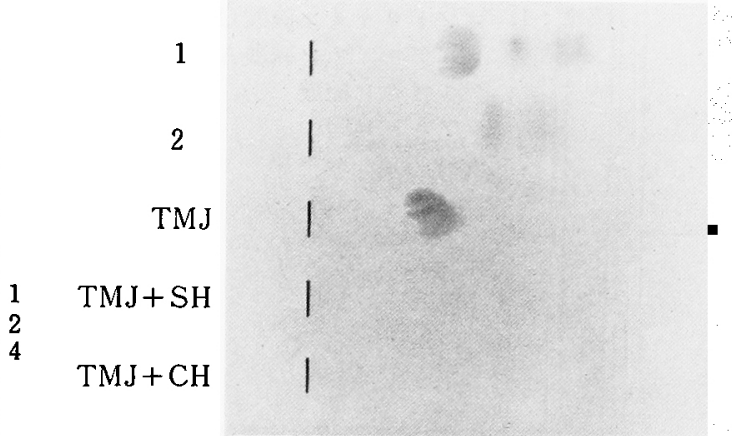

図 4 対照群须関節滑液 GAG の一次元電気泳動図

標準 : 1. コンドロイチン硫酸 $\mathrm{C}$

$$
\text { フンドロイチン硫酸 } \mathrm{A}
$$$$
\text { デルマタン硫酸 }
$$$$
\text { ヒフルロン酸 }
$$

2. ヘパリン

ヘパラン硫酸

TMJ : 䫁関節滑液

$\mathrm{SH}:$ ストレプトミセスヒフルロニダーゼ $\mathrm{CH}:$ コンドロイチナーゼ $\mathrm{ABC}$ 


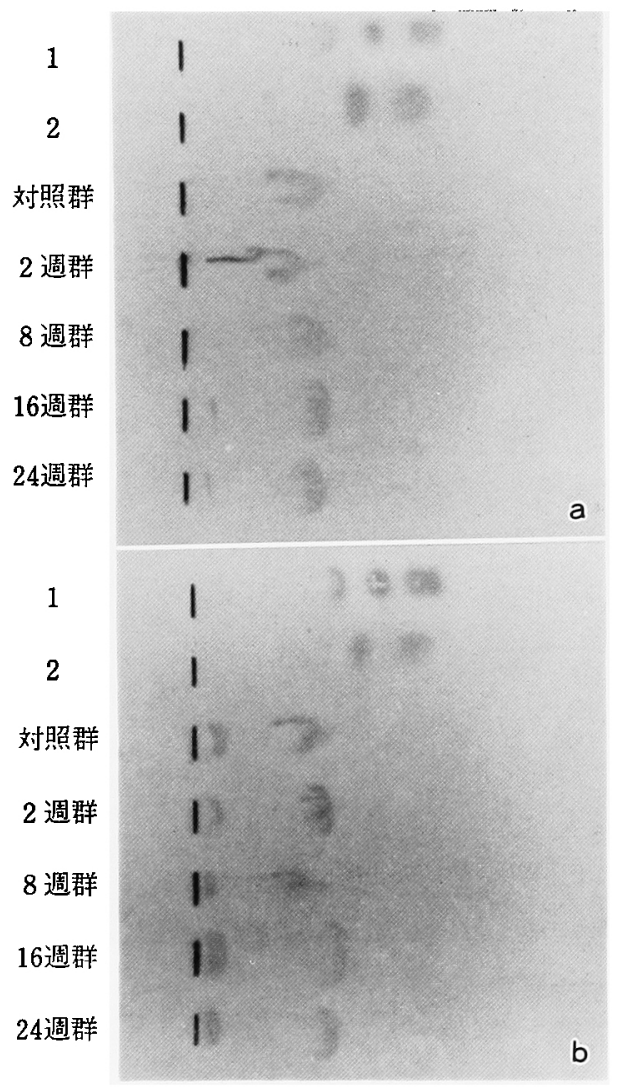

図 5 実臨群顎関節滑液 GAG の一次元電気 泳動図

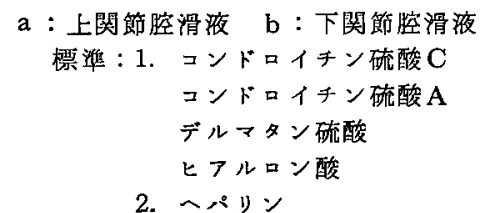
ヘパラン硫酸
た16および 24 週群でも，対照群に比べ有意（ $\mathrm{p}<0.01$ ， $\mathrm{p}<0.01)$ に低值を示した。 さらに，8週群では 2 週群 に比べ，有意差は認められないるのの，低下する傾向が 認められ，16 週群は 8 週群に比べ, 有意 $(\mathrm{p}<0.05)$ K 低下し，24週群は16週群に比べはとんど変化は認められ なかった（図6）。

\section{3 ）額関節滑液中の GAG の分子量分布}

顎関節滑液 GAG 加水分解物の HPLC のクロマトグ ラムでは，ウロン酸異性体として内標準であるガラクッ ロン酸とグルクロン酸のピークが認められたのみでイズ ロン酸のピークは認められなかった（図7）.すなわち, 電気泳動で得られた結果之同様に，GAGとして回収し た試料中には HA のみが含をれ、デルマタン硫酸やへ パラン硫酸は存在しないことが示された。これを基に， グルクロン酸のピーク高ざを HA のゲル濾過によるク ロマトグラムの指標とした。

奏験群および対照群の顎関節滑夜 GAG のゲル濾過の クロマトグラムは，ガラクッロン酸 (内標準)に対する グルクロン酸のピーク高さの比から求めた。

各クロマトグラムを検討すると（図 8), 対照群では， シャープな立ら上がりの比較的幅のせまいピークである のに対し2 週群では，ピークの位厧が低分子方向に偏位 しややなたらかなクロマトグラムとなった。 8 週群で は，さらにピークがやや低分子方向に偏位した．16週群 ではピークの位眉は 8 週群と比べさらに低分子方向に偏 位しなだらかな幅広いピークとなった。このように対 照群から16週群までは，ピークの溶出位置は遅くなり， HA の分子量分布は低分子方向への移動傾向を示した. しかし，24週群ではピークの溶出位置は16週群と比べ早 くなり，2 週群の溶出位置に近つくことから，HA の 分子量は低分子化から回復する傾向が認められた。

考察

䫇関節症の病因については諸説があるが，不良補緅物 による咬頭干涉や早期接触，あるいは曰歯欠損などの峧 合異常は重要な因子として考えられている。そのため,

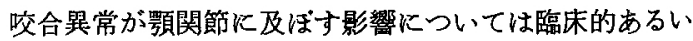

表 2 头臨群および対炤群の頻関節滑液 $\mathrm{GAG}$ 中の ウロン酸量 (単位 $: \mathrm{mg} / \mathrm{ml}$ )

\begin{tabular}{c|c|c|c|c|c}
\hline サル個体No. & 1 & 2 & 3 & 4 & mean土S.E. \\
\hline 対炤群 & 2.50 & 2.19 & 2.19 & 1.65 & $2.13 \pm 0.154$ \\
2 週群 & 1.37 & 1.59 & 1.88 & 1.64 & $1.62 \pm 0.090$ \\
8 週群 & 1.37 & 1.56 & 1.46 & 1.65 & $1.51 \pm 0.051$ \\
16 週群 & 0.90 & 1.36 & 1.15 & 1.31 & $1.18 \pm 0.089$ \\
24 週群 & 0.92 & 1.29 & 1.24 & 1.02 & $1.12 \pm 0.076$ \\
\hline
\end{tabular}




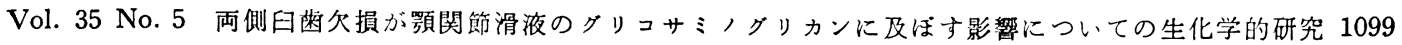

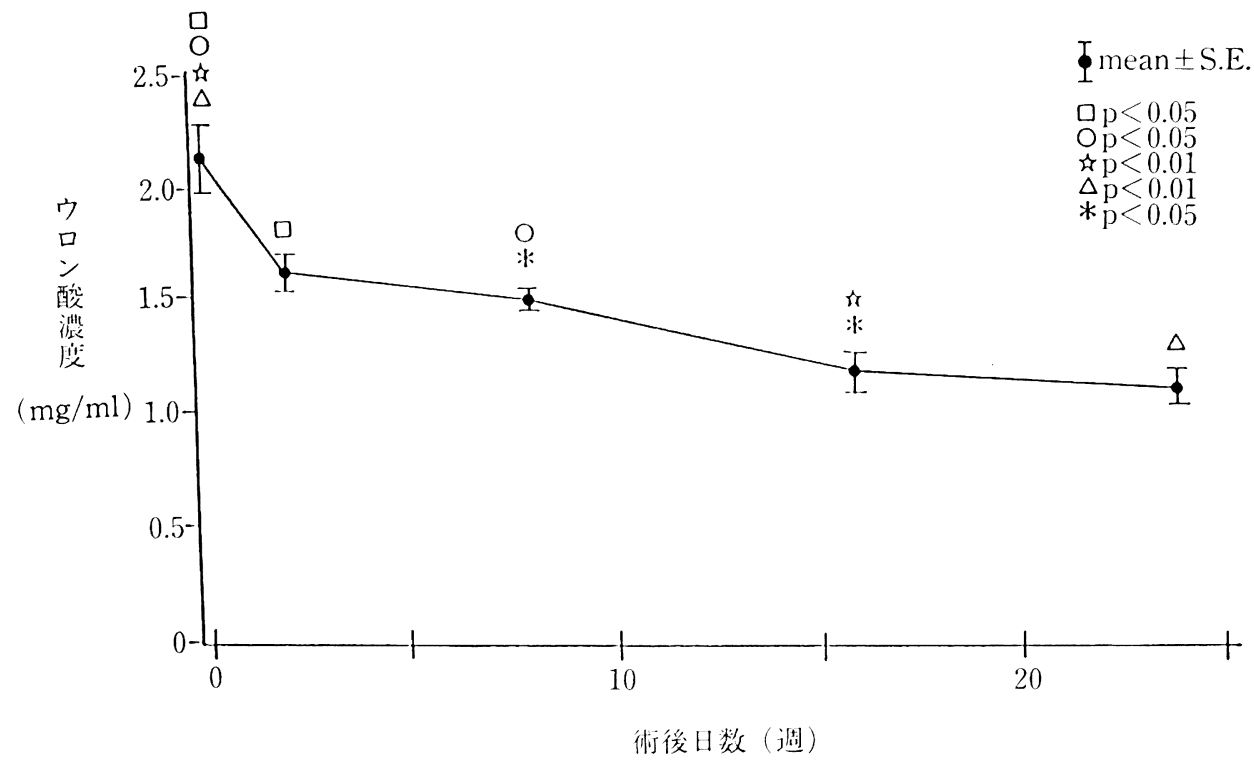

図 6 実験群扣よび対照群の䫇関節滑液 $\mathrm{GAG}$ 溜度の推移

结実験的に数多くの研究がなされてきた1 7,14 19). 関17) 俚, 顎関節症患者の $2 / 3$ に静的咬合関係の異常がみられ たと述べ，鬼㙇 ${ }^{18)}$ は，顎関節症汇関する臨床的研究で， 顎関節症の 7 割以上が 咬合異常に起因すると述べてい

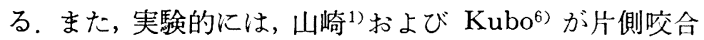
挙上による咬合異常について, Avantら ${ }^{14)}$, Cimasoni ${ }^{15)}$, Furstman $^{16)}$ ，喜久田 ${ }^{2)}$, 桶田 ${ }^{3)}$ および Ueno ${ }^{5)}$ が畨の欠 損による咬合異常についてそれぞれ検索し，枵関節に組 織学的あるいは超微構造的変化の生じることを報告して いる，一方，関節の潤滑に関与している滑液は，森本?

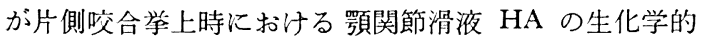
検討を行い，挙上側顎関節滑液 HA の早期減少と, 6 週以後の回復を報告している研究があるのみである.

HA は, Meyer ら ${ }^{20)}$ によってウン硝子体より単離命 名された GAG であり，滑液の主要構成成分である。生 体内での HA の生理的機能としては, 蛋白と結合して 細胞間で結合水をとり，ジェリ一状のマトリックスを形 成して細胞を保持し滑剤として働くとともに，細胞間物 質の移動の制御，外力やバクテリアの侵襲に対する保 護, 創傷治癒作用, リンパ球の幼若化抑制作用, 白血球 の食作用抑制などがあげられており ${ }^{21)}$ ，HA は関節が正 常な機能を営むために重要な成分であると考えられる.

そこで，歯の丧失によってひき起こされた咬合異常時 の靧関節滑液中の HA の動態を知るために, 森本の研 究をさらに進めて, 本実験では滑液中 $\mathrm{GAG}$ の同定とそ

図7 対照群顎関節滑液 GAG 加水分 解物の HPLC クロマトグラム 1. グルクロン酸 2. ガラクツロン酸

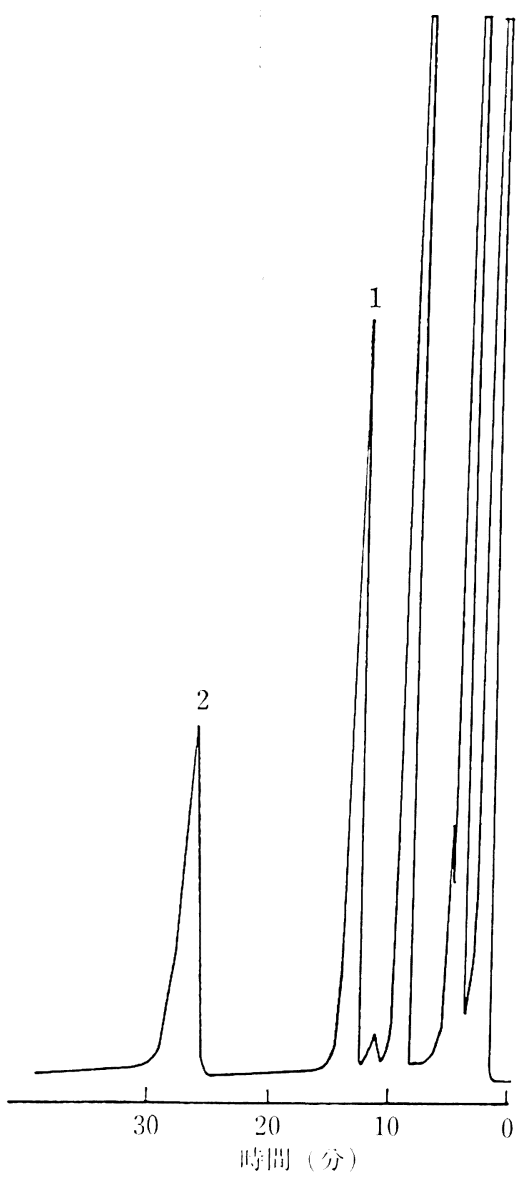




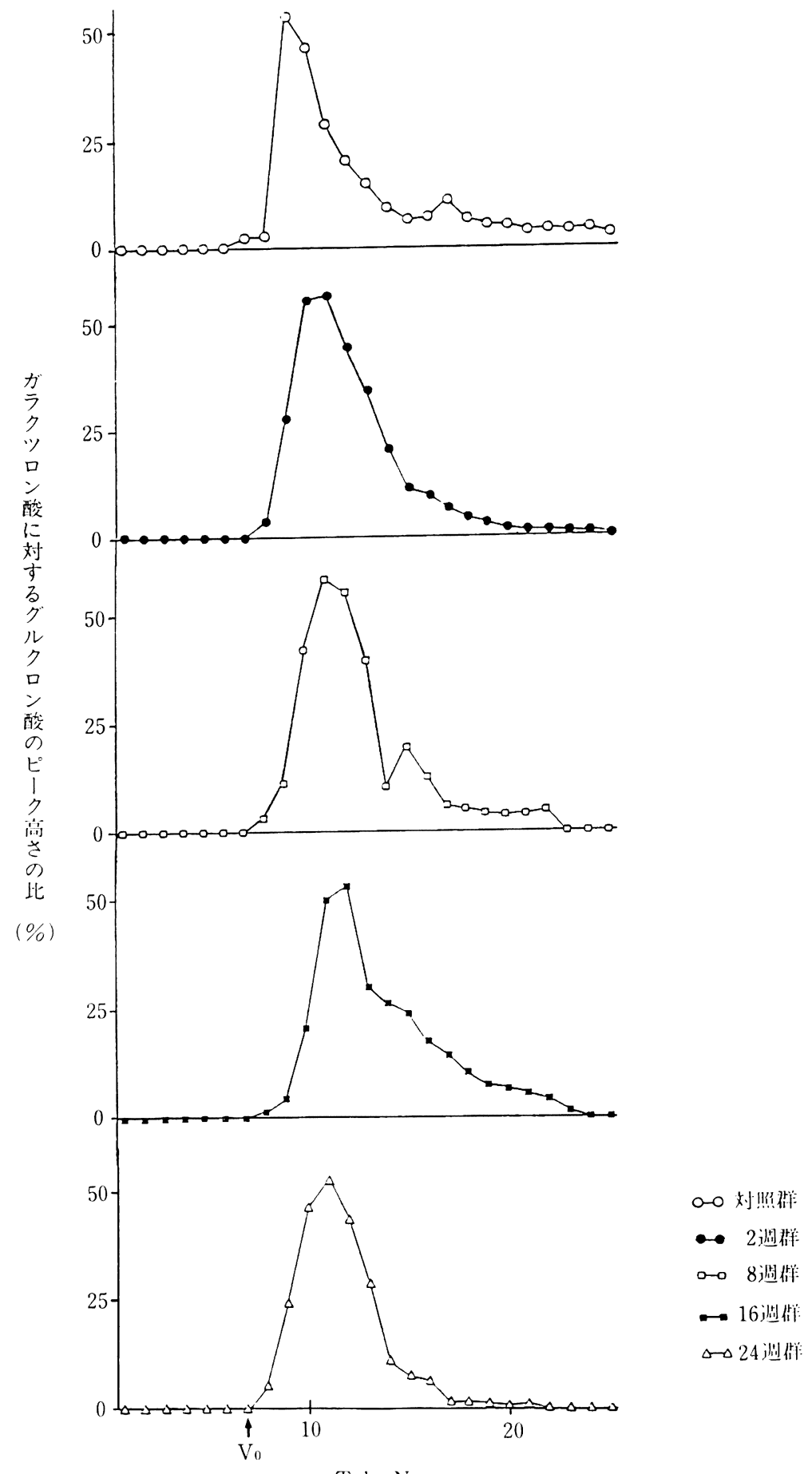

Tube No.

図 8 実験群および対照群の顎関節滑液 GAG の Sepharose CL2B クロマトグラム 
の量的変動, さらに分子量分布を検討した.

その結果, 㴿関節滑液中の GAG には, 実験群, 対照 群ともに HA のみが検出され, 他の GAG は認められ なかった。吉良 ${ }^{22}$ は，正常膝関節滑液では同定できなか ったコンドロイチン硫酸（以下，CS と略す）が膝関節 リウマチの患者に限り存在し, HA/CS 比は重症化に伴 って低下寸る傾向があると述べている。また，桑野23) も 種々の滕関節疾患の滑液には HA 以外に CS が存在し たと述べている。このように滑液中の CS の出現は, 関節疾患と関連性があると示唆されており，その由来に ついては軟骨からの分解産物 ${ }^{24)}$ ，あるいは滑膜細胞にお ける合成の結果である ${ }^{25}$ などの見解があり，その詳細は 不明である。しかし，本実験では CS は同定されなかっ た。これは，本実験が顎関節構成体に強い炎症を起こさ ない程度の両側臼歯欠損といら比較的的わかな実験条 件であったことに起因するのかもしれない

Hatton $5^{26)}$ は, ウシ頸関節滑液中のウロン酸濃度を Bitter-Muir 法で測定し, 得られた值を定数 (2.06) 倍し て HA 濃度を算出し, 上関節腔では $1.94 \pm 1.31 \mathrm{mg} / \mathrm{ml}$, 下関節腔では $2.06 \pm 0.83 \mathrm{mg} / \mathrm{ml}$ であると報告してい る。また，森本”ははカニクイザル靧関節滑液中の $\mathrm{HA}$ 濃度を細管式等速電気泳動装置で測定 し, $3.97 \mathrm{mg} / \mathrm{ml}$ であると述べている，本実験では，カニクイザル顎関節 滑夜中の GAG は HA のみから構成されていたので, ウロン酸値から HA 濃度を算出した。 その結果, 対照 群では $4.39 \mathrm{mg} / \mathrm{ml}, 2$ 週群では $3.34 \mathrm{mg} / \mathrm{ml}, 8$ 週群で は $3.11 \mathrm{mg} / \mathrm{ml}, 16$ 週群では $2.43 \mathrm{mg} / \mathrm{ml}, 24$ 週群では $2.30 \mathrm{mg} / \mathrm{ml}$ であり, HA の濃度は, 術後 2 週から16週 までは漸減し，以後はほとんど変化せずに推移した。対 照群の HA 濃度 $4.39 \mathrm{mg} / \mathrm{ml}$ を他の研究結果と比較す ると，細管式等速電気泳動装置て測定したカニクイザル 顎関節滑液中の濃度とほぼ同し值であるが，ウン顎関節 滑液中の源度よりやや高值となっている。この理由とし ては，Hatton らの実験で使用したウシが成牛であるの に対し，本実験で使用したカニクイザルが若猿であると いう実験動物の年齢差による要因と, ウシは切歯群と日 歯群の間にかなり広い電隙を有していることや, ウシの 関節円板には線維軟骨が存在している2iことから咬合様 式がサルと異なっているといら動物種による要因があげ られる。しかし，実験動物の滑液中の GAG 濃度の加路 变化や咬合様式について検索した報告はほとんど想めら れないので今後の検討が必要である.

ところで，HA の前駆物質であるグルコサミン-6- ${ }^{3} \mathrm{H}$ は滑膜紐胞のゴルジ装置に取り込まれること年，またヒ 卜正常膝関節滑膜培養液中にも HA が存在すること到 が確認されていることから，滑液中に分泌される HA は一般的に滑膜細胞で合成されると考えられている。 そ のため，顎関節構成体に何らかの異常が生ずれば HA の合成, 分泌系に障害の起こることは十分推測される.
樋田 ${ }^{3)}$ は，両側田崡欠損のサル顎関節について下顎 頭, 関節後突起の骨吸収と骨添加を病理組織学的に経日 的に観察し，骨変化は術後早期にはじまり，120１80日 後には停止すると述べている。またこの知見から，下顎 は両側下顎臼歯欠損により遠心移動をしたのではないか と推察している。本実験でも，HA 濃度の低下は実験初 期にはじまり，以後術後16週まで続くといら結果を得て おり, 植田の病理組織学的所見を滑夜の生化学的分析值 からも襄づける結果となったＨA 濃度の低下の原因と しては, 滑膜の透過性え進による浸出液増加のための希 釈効果や，滑膜細胞の機能障害が考兄られる。本実験群 では各群の滑液量に変化が認められなかったことから，

HA 濃度の低下は主として後者の理由によると思われる が, 採取滑液量が非常に微量であることから前者の理由 も否定できない

䫇関節滑液のHA の分子量分布は術後 16 週まで低分 子化傾向を示した。一般に病的滑液中で HA 濃度が低下 し，低分子化が起こることについては数多くの報告 ${ }^{30 ~ 33)}$ がある。低分子化の原因としては滑膜細胞での重合障害 や GAG 分解酵素活性の六進が考えられる. GAG 分解 酵素の由来について, 浅井 ${ }^{34}$ は血清中および滑液中の七 アルロニダーセ活性を測定し, 後者が前者を越えること がないことから、滑液中のヒアルロニダーゼは血清に由 来するものであり，滑膜の透過性の変化によって関節腔 内に浸出するのではないかと結論づけた。蛋白質レベル の高分子物質の滑膜における透過性制御機構について, Kakudo ${ }^{35}$ は滑膜の毛細血管の選択的透過性とともに滑 膜 $\mathrm{A}$ 型細胞のもつ高分子物質取り込又能がその制御機構 に強く関与していることを電顕細胞化学的に明らかにし ている。ささらに Ueno ${ }^{5)}$ はラット臼歯拔歯後の靧関節滑 膜の変化を電顕的に観察し, 滑膜 $\mathrm{A}$ 型細胞に变性が起こ り，変性の程度に応して経静脈的に投与した horseradish peroxidase の取り込みが漸次減少し, 变性は術後16週ま で続くと述べている。この電顕所見は, 本実験での HA の低分子化の時期と一致している。これらの所見を考え 合わせると, GAG 分解酔素活性の克進の機序について は, 抜雨に伴う咬合変化により滑膜 $\mathrm{A}$ 型細胞に变性が生 じ，ライソゾーム醉素の一つである GAG 分解酵素が細 胞外に放出されるとともに, A 型細胞による滑膜透過制 御機满が破綻し血清中の GAG 分解醉素が浸出すること によるものと考えられる.

顎関節の左右側 および上下関節腔による差異につい ても報告されている，左右䫇関節に同条件を付与した Furstman ${ }^{16)}$ は両側間汇組織学的に明らかな变化を認め ていない，また，上関節腔滑液と下関節膑滑液の差につ いては，有意差のないことを森本〕が報告している。本 実験では Furstman と同様に左右顎関節に同条件を付与 しているため, 両側嘪関節滑液を合わせて実験試料とし た。 
顎関節症患者の下顎窩と下顎頭の形態的変化および下 顎頭の位置的変化についての報告 ${ }^{36 \sim 43)}$ は多く, 上村ら ${ }^{40)}$ は，顎関節症患者の顎関節規格エックス線写真を分析 し，対象とした 601 例中 295 例 $(49.1 \%$ ）に異常が認め られ, 年齢別では40歳以上の症例に形態異常の出現率が 高いと述べている。本実験では, 形態的变化は認められ なかったがこれは実験動物が歯牙年齢 $\mathrm{M}_{2} / \mathrm{M}_{2}$ と若齢 であることや，最長実験期間が 24 週であるため骨変化が 生ずるに至らなかったためであろう。

また，山内ら ${ }^{39)}$ はェックス線写真像から，靧関節症 患者は下顎頭位の前後的偏位が著明であると述べ, Weinberg ${ }^{42)}$ は 138 名の㴿関節症患者のエックス線写真 分析から，下縜頭偏位は約 $90 \%$ に認められたと述べてい る。これらはいずれも正常者と買関節症患者の比較で, 同一個体の経日的な变化を観察したものではない 本実 験の顎関節規格エックス線写真による分析では, 鼻聴道 線を基準として同一個体北術後16〜24週で後上方方向へ の下顎頭の偏位がみられた。この理由として下顎自体の 位置移動あるいは前来の咬耗による咬合低下があげられ るが，抜歯部上下雨槽堤が術後16〜24週でほぼ接してい ること，また術後の模型上で前歯の咬耗が汪とんど観察 されないことから，主として前者の理由により下顎頭の 偏位が起こったのではないかと推察される。

以上のことから, 本実験の HA 濃度の低下と低分子 化は，次のような原因でひき起こされたものと考えられ る.すなわち目歯の支持が喪失することにより，主とし

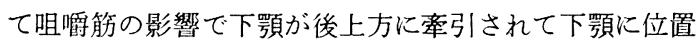
移動が起こり, それによって顎関節構成体に異常負荷が かかって滑膜細胞が障害され, 慢性外賃性病変が惹起さ れるといら考え方である。また，分子量低下の回復が HA 濃度低下の停止とほほ同時期に起こっていることか ら, 滑膜B型細胞での HA の合成分泌障害はまた継続 しているものの, GAG 分解酵素活性は低下している状 態ではないかと推察される。酵素活性の低下について は, 術後16週から 24 週にかけて上下顎目霜部が泳淁す ることにより, 罘関節構成体にかかる負荷が軽減して,

滑膜細胞の崩壞变性に回復傾向が認められ, ラインゾー ムからの醅素の放出が減少し, さらに細胞变性に伴う毛 細血管の選択的透過性と高分子物質取り込又能の制御機 構が回復するため起こるのではないか, すなわち田雨 欠損といら状態に対して，生体内で順応が起こりつつあ るのではないかと考えられるが，さらに実験期間を延長 して生化学的ならびに超微構造的に検討する必要があ る. 整形外科領域において, 滑液, 特に膝関節滑液は疾 患の診断に日常的に用いられているが䫇関節領域では, 解剖学的構造の複雑さと, 液量が微量なことから滑液は 診断には用いられていないのが現状である。また，実験 系においても上記の理由により, 顎関節滑液について検 索したものはほとんどない、先に、森本〕は，片側咬合
挙上したサル 㴿関節滑液中の HA 量を細管式等速電 気泳動装置を用いて測定し，挙上側買関節滑液中の HA は，術後 1 週まで減少し， 6 週以後で回復することを報 告しているが, 本実験では, 定性, 定量に加えて分子量 分布の検討を行うため,さらに高感度な測定方法を必要 とした。武田ら ${ }^{44)}$ の報告したプレラベル化剂としてダン シルヒドラジンを用いたウロン酸の HPLC 法による定 量は, 前処理の簡便さと, $0.1 \sim 20 \mathrm{nM}$ の微量範用での ウロン酸の定量測定が可能である点から有用と考えられ た。そこで生体試料中のウロン酸を定量するために武田

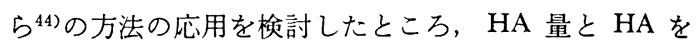
加水分解して得たグルクロン酸のピーク高さとはよく相 関する結果が得られた ${ }^{13)}$ しかし，HA とCS はとも に構成糖としてグルクロン酸を含んでいるため HA と CS が混在する試料では相互の分離定量はできない。こ のため，CS が混在する試料では，これを酔素消化して 得られる不飽和二糖 $(\triangle \mathrm{Di}-0 \mathrm{~S}$ と $\triangle \mathrm{Di}-4 \mathrm{~S}, \triangle \mathrm{Di}-6 \mathrm{~S})$ レベルでの分析が必要と考えられる。不飽和二糖の分析 に本法を応用すれば，臨床的に採取したヒ卜顎関節滑液 中の GAG 微量分析が可能となり, 靧関節症の診断に寄 与するものと考えられる。

HA の鎮痛作用や抗炎症作用 ${ }^{45}$ についてはすでに報告 されているが，HA は，変形性滕関節症患者の治療にも 用いられて㧍り, 大島ら ${ }^{46)}$ は, 変形性膝関節症患者の関 節腔内に高分子量 HA ナトリウムを投与し, 臨床項目 別評価では, 疼痛の改善率が最も高く, また有効率は $\mathrm{HA}$ ナトリウムの $1 \%$ 水溶液を 1 週間隔で $2.5 \mathrm{ml}$ 投与 した群で最も高く $67.9 \%$ であったと述べている。ささらに 最近, GAG ポリ硫酸エステルが, 䐂関節滑膜の HA 生 合成汶対して促進作用を有することが証明され，その臨 床応用がなされている。満田ら ${ }^{47)} は$, 变形性膝関節症の 患者に GAG 製剤の投与を行い，ほとんどの症例で HA の濃度, 粘調度の増加に伴って疼痛と歩行能力の改善が みられたと報告している。顎関節領域においても变形性 顎関節症患者に対する HA ナトリウムの関節腔内注射 法が施行されており, ステロイド投与群と比較し, 有効 性に有意差はなく, 副作用の危険性はほとんどないと報

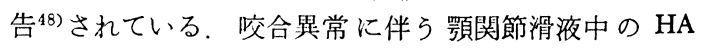
濃度の低下および低分子化が顎関節症の誘因になってい るとすれば, 高濃度, 高分子量 HA の関節腔への投与 は有効な治療法であるが，関節腔内に投与した HA ナ トリウムはほぼ 3 日で関節腔内から消失するという報 告49)もあり, 投与浱度, 回数については今後の検討が待 たれるところである.

靧関節症については，本邦において上野50) が顎関節 痛, 関節雑音, 異常顎運動を主症状とする非炎症性の慢 性顎関節疾患の臨床診断名を顎関節症として総括して以 来, さまざまな研究が行われ，エックス線技術の進歩や 関節鏡視法の発達により診断成緽は向上し，それに伴い 


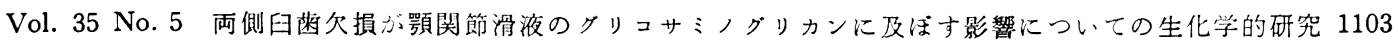

治療成績も向上している．現在，臨床的に頡関節症の診 断には罘運動機能検査, 筋電図, エックス線解析, MRI などが用いられているが，それらに滑液の生化学的分析 が加われば，㴿関節症に対してより確実な診断基準を設 定できるものと考えられる。

\section{結 論}

両側且歯欠損に起因する咬合異常時の䫇関節滑液 GAG の分子種レベルの動態を生化学的に分析した.

1. 顎関節規格エックス線写真では，洖験群の下顎頭 および下㴿窩に経日的な形態的変化はほとんと観察され なかったが，下㴿頭の位置的变化は術後16〜24週で鼻聴 道線を基準として後上方への偏位として観察された。

2. 顎関節滑液 GAG は，HA のみで構成されている ことがセルロース・アセテート膜電気泳動および酵素消 化で確認された。

3. ウロン酸量であらわした滑液中の HA 濃度は, 対 照群では $2.13 \mathrm{mg} / \mathrm{ml}$ であり, 実験群では術後 16 週ま で経日的に低下傾向を示し， 16 週では対照群の約 $1 / 2$ $(p<0.01)$ となり，以後その值に変動はなかった。

4. Sepharose CL 2 B ゲル濾過の買関節滑液 GAG 溶 出位置は, 対照群に比べ, 実験群では術後 2 週群から16 週群まで経日的に遅延し，24週群ではこの遅延が 2 週群 の位置まで回復する傾向を示した。

以上の結果から，両側曰雨欠損により，顎関節構成体 に異常な負荷がかかると慢性外鹪性病変が惹起され, 顎 関節滑液単位容積あたりの HA 濃度は術後経日的に低 下し，また同時に HA の低分子化傾向をひき起こすこ とが示咬された。

本論文の一部は，第 1 回日本顎関節学会（昭和63年 7 月 2 日 名古屋市) で, また要旨は第 375 回大阪㴹科学 会例会（昭和63年11月12日 大阪市）で発表した。

なお，本研究の一部は昭和 62 年度大阪渵科大学学術研 究奖励金助成に上りなされたもので劣る。

稿を終えるにあたり，ご琶切なご指導とご校閲をいた だきました大阪遒科大学口腔外科学教室第 1 講座恩師白 数力也教授, ならびに大阪茵科大学生化学教室㮵 鉄也 教授に深甚の謝意を表します。ま仙直接のご指導とご助 言をいただきました大阪菌科大学口腔外科学教室第 1 满 座覚道健治鹪師, 大阪幽科大学生化学教空藤田 厚助教

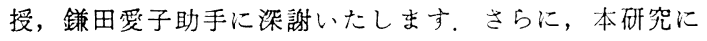
ご協力くださった口腔外科学教室第 1 煐座教室員ならび に生化学教室教室員各位に謝意を表します。

\section{引用 文 献}

1）山崎 博：片㑡咬合挙上による両㑡靧関節の変
化に関する実験的研究。九州濑会誌 33：2572801979.

2）喜久田利弘：片側㮸牙欠損によるサ几顎関節の 病理組織学的研究。九州㳡会誌 34: 254-274 1980.

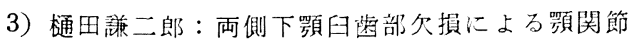

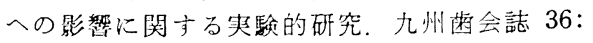
136-156 1982.

4）鬼塚啓史・咬合挙上冠除去後の顎関節への影響

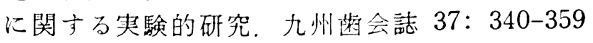
1983.

5) Ueno, S.: The uptake of horseradish peroxidase in the temporomandibular joint synovium of the rat following unilateral extraction of molars. J Dent Res 61: 516-520 1982.

6) Kubo, Y.: The uptake of horseradish peroxidase in monkey temporomandibular joint synovium after occlusal alteration. J Dent Res 66: 1049-1054 1987.

7) 森本伊智郎：片側咬合挙上時に打ける顎関節液 ヒアルロン酸の量的卒動に関京万研究。日口外 誌 33: 21-31 1987.

8）荒木春美, 覚道健治, 他: サ几用靧関節規格工 ックス線撮影法の基礎的㭘討と撮影装置の考 穼. 口科誌 37: 600-608 1988 .

9) Hata, R. and Nagai, Y.: A rapid and micro method for separation of acidic glycosaminoglycans by two-dimensional electrophoresis. Anal Biochem 45: 462-468 1972.

10) Ohya, T. and Kaneko, Y.: Novel hyaluronidase from streptomyces. Biochim Biophys Acta 198: 607-609 1970.

11) Yamagawa, T., Saito, H., et al.: Purification and properties of bacterial chondroitinases and chondrosulfatases. J Biol Chem 243: 1523-1535 1968.

12) Bitter, T. and Muir, H.M.: A modified uronic acid carbazole reaction. Anal Biochem 4: 330-334 1962.

13）鎌田要子, 荒木春美, 他：高速液体クロマトグ ラフィーによるウロン酸の微量定量法。药科医 学 52: 84-90 1989.

14) Avant, F.B., Averil, C.J., et al.: Changes in the temporomandibular joint of rats caused by alteration in the intermaxillary relationships of the teeth. J Dent Res 31: 499-500 1952.

15) Cimasoni, G.: Histopathology of temporomandibular joint following bilateral extraction of molars in the rats. Oral Surg Oral Med Oral Pathol 16: 613-621 1963.

16) Furstman, L.: The effect of loss of occlusion upon the mandibular joint. Am J Orthod 51: 245-261 1965.

17）関 秀莩: 頡関節症の補経学的研究 第 1 報 顎関節症患者の咬合汇関する研究，口病誌 35 : 
213-227 1968.

18）鬼塚謙治：顎関節症に関する臨床的研究，九州 宷会誌 30：662-708 1977 .

19）林 清平：実験的咬合千涉が咀噒系に与える影 整。菻学 70：687-764 1982.

20) Meyer, K. and Palmer, J. W.: The polysaccharide of vitreous humor. J Biol Chem 107: 629-634 1934.

21）並木脩：ヒアルロン酸の生理機能拈よび医学 的応用について。整形外科 29：553-561 1978.

22）吉良貞雄：病的関節液の Hexosamine ならびに Acid Mucopolysaccharide に関する研究。日整 会誌 41：1-16 1967.

23）桑野 茂：病的関節液中の酸性么コ多桾に関す 万研究. 医学研究 39: 199-221 1969.

24) Silpananta, P., Dunstone, J.R., et al.: Fractionation of hyaluronic acid preparation in a density gradient. Biochem J 104: 404-409 1967.

25）猪狩 忠編：整形外科 MOOK 32 関節疾患と 関節液。第 1 版，金原出版，東京，1984，24-37 頁.

26) Hatton, M.N. and Swann, D.A.. Studies on bovine temporomandibular joint synovial fluid. J Prosthet Dent 56: 635-638 1986.

27）鉿木 禎：各種動物の顎関節円板にみられる軟 骨細胞の分布並びに機能的意義について1. 各 種動物の顎関節円板の組織構造。绦報 71 : 1311-1336 1971.

28) Barland, P., Smith, C., et al.: Localization of hyaluronic acid in synovial cells by radioautography. J Cell Biol 37: 13-26 1968.

29) Castor, C.W.: Production of mucopolysaccharides by synovial cells in a simplified tissue culture medium. Proc Soc Exp Biol Med 94: 51-56 1957.

30) 近藤 仁：正常扣よび病的七ト関節液の粘性に 関する研究. 北里医学 10：485-498 1980.

31）斎藤直美：関節液の特性一七アルロン酸を中 心としたグリコサミノグリカンと㔻白につい て一。中部整災誌 26：1978-1987 1983.

32) Bjelle, A., Andersson, T., et al.: Molecular weight distribution of hyaluronic acid of human synovial fluid in rheumatic diseases. Scan J Rheumatol 12: 133-138 1982.

33) Dahl, L., Dahl, I.M., et al.: Concentration and molecular weight of sodium hyaluronate in synovial fluid from patients with rheumatoid arthritis and other arthropathies. Ann Rheum Dis 44: 817-822 1985.

34）浅井春雄: 血清拉よび関節液ヒアルロニダーゼ の比濁定量. 日整会誌 41：708-718 1967.

35) Kakudo, K.: Ultrastructural cytochemical studies of horseradish peroxidase uptake by synovial lining cells of the rat temporomandiburlar joint. Okajimas Folia Anat Jpn 57: 219-240 1980.

36）高久 遏 正常ならびに病的顎関節のX線学的 研究. 口外誌 7: 203-219 1961.

37) Weinberg, L.A.: Correlation of temporomandibular dysfunction with radiographic findings. J Prosthet Dent 28: 519-539 1972.

38）山内哲義, 中村公雄, 他: 㴿関節側方 $\mathrm{X}$ 線規格 写真による顆頭位の分析方法について。補緅誌 20: 193-206 1976.

39）平田周三：顎関節のX線学的研究一顎関節㑡斜 位撮影法により得られたX線像の分析一。九州 来会誌 32：374-392 1978 .

40) 上村修三郎, 中村太保, 他：顎関節疾患に関寸 万X線診断学的研究一顎関節症に打汁る関節 の形態的変化について一。萪放 19: 224-237 1979.

41) Weinberg, L.A.. Role of condylar position in TMJ dysfunction-pain syndrome. J Prosthet Dent 41: 636-643 1979.

42) Weinberg, L.A.: Clinical report on the etiology and diagnosis of TMJ dysfunction-pain syndrome. J Prosthet Dent 44: 642-653 1980.

43）竹之下康治, 中村昭一, 他 : 顎関節症の Schüller 氏変法X線像による観察. 日口外誌 27：5655721981.

44）武田素子, 前田昌子, 他：プレラペル化剛とし てダンシルヒドラシンを用いるウロン酸の高速 液体クロマトグラフィ. 分析化学 33: 681-683 1984.

45) 宮崎匡輔, 後藤幸子, 他: Sodium Hyaluronate (SPH)の鎮痛作用拉よび抗炎症作用. 応用薬理 28: 1123-1135 1984.

46) 大島良雄, 東 博彦, 他 : 変形性膝関節症に対 する高分子量ヒフルロン酸ナトリウム $(\mathrm{SPH})$ の関節腔内注射療法一他施設共同研究に上る臨 床第 II 相試験一。薬理と治療 11：2253-2267 1983.

47）满田基温, 山本浩司, 他: 変形性膝関節症に対 するフルテパロン囚の使用経験一滕関節液の分 析と臨床効果の対比一 医学と薬学 14：136313681985.

48) Kopp, S., Carlsson, G., et al.: Long-term effect of intra-articular injections of sodium hyaluronate and corticosteroid on temporomandibular joint arthritis. J Oral Maxillofac Surg 45: 929-935 1987.

49）坂本 崇, 水野祥二, 他: Sodium Hyaluronate (SPH) の体内動態 (第 1 報) ${ }^{14} \mathrm{C}-\mathrm{SPH}$ のウサ ギ関節腔内投与に扰ける分布, 代謝ならびに排 泄. 応用薬理 28：375-387 1984.

50）上野 正：罘関節疾患の診断と治療。日茵評論 170: 1-7 1957. 